LAmont, A., 1957. Slow anti-dunes and flow marks. Geol. Mag., xciv $472-480$.

Pierce, R. C., 1916. The measurement of silt-laden streams. U.S. Geol. Surv. Water Supply Paper 400-C, 41-3.

Prentice, J. E., 1956. The interpretation of flow-markings and load-casts. Geol. Mag., xciii, 393-400.

J. E. Prentice.

UNIVERSITY OF LONDON,

King'S COLLEGT,

StRAND, W.C.2.

4th Februarv, 1958.

\title{
LOAD-CASTS AND FLAME STRUCTURES
}

SIR, - At the risk of over-inflating an already dangerously distended literature on load-casts and related penecontemporaneous sedimentary structures, may I add a comment to the interesting account of Kelling and Walton in the November-December issue of the Geological Magazine for 1957. It is unusual to conceive that ripple-mark should develop in muddy sediments, and if it did its presence would be revealed by current bedding, at least for transverse and interference-ripples. I have examined hundreds of perfectly displayed load-casts, and although current bedding is sometimes to be seen in the overlying sandstones, $I$ have never seen it in the argillaceous under-beds. The authors have, however, reached a conclusion regarding the origination of mudstone injections from ripple crests that in all other ways agrees with my own, originally published many years ago (Roy. Soc. Vict., Vol. 53, 1941, pp. 167-91) and referred to (with illustrations) more recently in Outlines of Structural Geology (London, 1953, pp. 11-13) including diapirism, analogy with salt domes (based in 1941 on Nettleton's experiments), and the suggestion that asymmetry of "flame" structures may reflect slight differential movements during compaction. In the Victorian examples, however, the ripple mark is actually preserved on a sandstone underlying the injected mudstone, not on the mudstone itself. The notion deriving from the later experiments of Parker and Macdowell that the height of the mud-domes may be controlled by the thickness of superincumbent sand has not escaped the writer, who was perhaps in error on this point in 1941, and it is interesting to note that the "overhang " so characteristic of salt domes is common in mudstone injections, which do in fact approximate to a definite elevation in any one bed (Outlines, fig. 6D, p. 11). The possible influence of differential loading (even after deposition amounting only to something of the order of an inch of sand) must not, however, be overlooked. True pseudonodules of the type erected by Marcar and Antun (Bull. Soc. géol. Belg., vol. 73, 1950, pp. 121-49) most probably represent isolated or nearly isolated sand ripples with current-bedding (Outlines, fig. 6E) which sank into the soft mud developing flanges analogous with those of australites, due to fluid-dynamic moulding as they sank. Finally, I personally cannot resist the force of Sorby's beautiful illustrations and logic in ascribing flame structures and other mudstone injections in the Langdale slates, without any underlying ripples, to the breaking up of a deposit that was in a " creamy semi-liquid condition" (Quart. Journ. Geol. Soc., vol. 64, pp. 171-233), a conclusion that agrees well enough with the concept, unknown to him, of turbidity current deposition and with experiments with oil films on water, which faithfully reproduce flame structures by differential flow. According to this notion asymmetrical flame structures are Helmholtz waves modified by the rheid properties of the materials so that the "anticlines" become pointed and inject the sandstone. The occurrence of examples with an amplitude of 6 to 10 feet in basalt resting on carbonaceous clay at Berwick, Victoria, is particularly interesting from this point of view. With sediments believed to be deposited by turbidity 
currents it is more than a little difficult to decide what is to be regarded as "depositional" and what "post-depositional" in the way of small-scale structures, even with the one graded bed if this is complex, but, in the Victorian examples of salt-dome type mudstone injections, the beds (Silurian) are not strongly graded, but rather sharply defined alternating sandstone and mudstone. It was for this reason that the flame structures in them were regarded as post-depositional. Many examples in the Victorian Ordovician rocks, which are predominantly graded beds, are however to be ascribed to penecontemporaneous differential flow, as they are not related in any way to underlying ripples and there is widespread evidence for post-depositional flow of a few inches in the sandstones.

\section{E. Sherbon Hills.}

University of Melbourne.

24th February, 1958.

SIR,-We regret having overlooked Professor Hills' important contribution to the subject of load-cast structures, but are glad that we have, however tardily, reached conclusions in certain respects similar to his own.

It is true that flame structures are perhaps best developed in purely argillaceous sediments, but it is the case, at least in the Southern Uplands, that the deformed bed may be of silt or even fine-grained greywacke. The formation of transverse ripple marks is thus not excluded though as we point out in our paper (p. 487) load-casts developed from them appear to be rare. In the example given by Professor Hills of flames developing in mudstone above transverse ripples, the original irregularities in the clay would reflect the transverse ripples and the structures may still be termed T-ripple load-casts.

The main aim of our paper, however, was to point out that given sufficient density contrast, any surface irregularity may be exaggerated to produce a load-cast : transverse ripple-mark is one of these irregularities, but grooves and flutes appear to be more important.

Differential flowage may produce flow-casts which are similar to load-casts, but so long as some of the original structure is retained the two forms can be recognized. In the rocks of the Southern Uplands we believe load-casting to be the dominant process but a general evaluation of their relative importance is an interesting task for the future.

Grant Institute of Geology,

G. KeLLING,

F. K. Walton.

West MaINS ROAD,

EDINBURGH 9.

10th March, 1958.

\section{IGNEOUS ROCKS AT GOREI, SHILEMADU RANGE, BRITISH SOMALILAND}

StR,-May I add a postscript to Dr. J. E. Mason's interesting account (Geol. Mag. xciv, p. 498)?

Leckie's preliminary report on the geology of the Protectorate published in 1905 (1) seems to have been written whilst he was still in that country but presumably before he had seen the Gorei ( $8^{\circ} 58^{\prime} \mathrm{N} ., 47^{\circ} 48^{\prime} \mathrm{E}$.) exposure of which he makes no mention.

I have found no later published account by him, and the bricf description of the geology of the country given in the Military Report on Somaliland, 1907 (2), does not refer to Gorei. But of the three attached maps, the two topographical sheets mark both Gorei and the Shilemadu Range, and the 